UDK 378.147-029:82-7

Izvorni znanstveni rad

Primljeno: 26.1.2021.

\author{
Tea FILEŠ ${ }^{1}$, Nina PAVLIN-BERNARDIĆ² \\ 'Zagrebačka banka d.d., Zagreb, Hrvatska \\ 2Odsjek za psihologiju Filozofskog fakulteta u Zagrebu, Hrvatska \\ nbernardi@ffzg.hr
}

\title{
STILOVI HUMORA SVEUČILIŠNIH NASTAVNIKA KAO PREDIKTORI EVALUACIJE NASTAVNIKA I MOTIVACIJSKIH ČIMBENIKA U STUDENATA
}

Sažetak Cilj ovog istraživanja bio je ispitati doprinos stilova humora studenata i nastavničkih stilova humora u objašnjavanju evaluacije sveučilišnih nastavnika i motivacijskih čimbenika u studenata: ispitne anksioznosti, vrijednosti zadatka i akademske samoefikasnosti. Istraživanje je provedeno putem ankete online na uzorku od 290 studenata različitih fakulteta. Sudionici su ispunjavali skalu nastavničkog humora, skale vrijednosti zadatka, akademske samoefikasnosti i ispitne anksioznosti, upitnik evaluacije nastavnika i upitnik stilova humora. Rezultati pokazuju da je prikladan humor nastavnika pozitivan, a neprikladan humor negativan prediktor evaluacije nastavnika. Za motivacijske čimbenike dobiveni su sljedeći rezultati: afilijativni stil humora studenata je negativan, a samoporažavajući stil pozitivan prediktor ispitne anksioznosti, dok se stilovi humora nastavnika nisu pokazali statistički značajnima. Agresivni stil humora studenata i neprikladan humor nastavnika su pozitivni, a samopoboljšavajući stil humora studenata i prikladan humor nastavnika negativni prediktori vrijednosti zadatka. Afilijativni i samopoboljšavajući stil humora studenata te prikladan humor nastavnika su pozitivni, a agresivni stil humora studenata je negativan prediktor akademske samoefikasnosti. Dobiveni rezultati upućuju na doprinos humora u obrazovnom kontekstu kao i na poželjnost korištenja humora na nastavi. Ključne riječi: humor nastavnika; stilovi humora; evaluacija nastavnika; motivacijski čimbenici

\section{UNIVERSITY TEACHERS' HUMOUR STYLES AS PREDICTORS OF TEACHER EVALUATION AND MOTIVATIONAL FACTORS IN STUDENTS}

\begin{abstract}
The aim of this study was to examine the contribution of university students' humour styles and their teachers' humour styles in explaining teacher evaluation and motivational factors: test anxiety, task value and academic self-efficacy. The study was conducted through an online survey on a sample of 290 university students from different faculties. The participants completed instructor humour scale, test anxiety, task value and self-efficacy for learning and performance scales, teacher evaluation questionnaire and humour styles questionnaire. The results showed that an appropriate teacher humour is a positive predictor of teacher evaluation, while an inappropriate teacher humour is a negative one. The following results were obtained for motivational factors: students' affiliative and self-defeating humour styles are positive predictors of test anxiety. Students' aggressive humour style and inappropriate teacher humour style are positive predictors, while students' self-enhancing humour style and appropriate teacher humour style are negative predictors of task value. Students' affiliative and self-enhancing humour styles and appropriate teacher humour style are positive predictors of academic self-efficacy, while students' aggressive humour style is a negative predictor of academic self-efficacy. The obtained results indicate the contribution of humour in the educational context as well as the desirability of using humour in teaching.
\end{abstract}

Key words: teachers' humour; styles of humour; teacher evaluation; motivational factors 
TEA FILEŠ, NINA PAVLIN-BERNARDIĆ: STILOVI HUMORA SVEUČILIŠNIH NASTAVNIKA KAO PREDIKTORI EVALUACIJE NASTAVNIKA I MOTIVACIJSKIH ČIMBENIKA U STUDENATA

\section{Uvod}

Humor predstavlja zajednički naziv za sve crtane, pisane i verbalno iznesene sadržaje koji u ljudi izazivaju fiziološke i emocionalne reakcije poput smijeha i veselja (Brozović, 2004). Martin i Ford (2018) navode da ljudi koriste humor kako bi prikazali sebe u dobrom svjetlu ili kako bi poboljšali odnos s drugima. Moguće je koristiti dobronamjeran humor, koji ne vrijeđa druge ni vlastito poimanje, ali i humor koji je potencijalno štetan za nas ili za druge (Martin, PuhlikDoris, Larsen, Gray i Weir, 2003). Prema tome, postoje četiri stila humora koje ljudi svakodnevno koriste: afilijativni stil, kojem je cilj povezivanje s drugim ljudima i smanjivanje napetosti, samopoboljšavajući stil, kada osobe koriste humor u stresnim ili frustrirajućim situacijama kako bi ih lakše podnijele, agresivni stil, koji je je izravno usmjeren na ismijavanje drugih i samoporažavajući stil, usmjeren na ismijavanje vlastitih nedostataka i propusta.

Afilijativni i samopoboljšavajući stilovi uključuju dobronamjernu uporabu humora i imaju pozitivan učinak na psihološke i socijalne čimbenike (Abel, 2002; Martin i dr., 2003; Vernon, Martin, Schermer i Mackie, 2008). Prema navedenim istraživanjima, takvi oblici humora pokazuju pozitivnu povezanost sa samopoštovanjem, optimizmom i socijalnom potporom, a negativnu s anksioznošću i depresijom. S druge strane, agresivni i samoporažavajući stil negativno su povezani s psihološkim zdravljem i dobrobiti te samopoštovanjem i socijalnom potporom, a pokazuju pozitivnu povezanost s agresijom i neprijateljstvom, anksioznošću i depresijom (Martin i dr., 2003; Vernon i dr., 2008; Veselka, Schermer, Martin i Vernon, 2010).

Humor ima pozitivne i negativne utjecaje na psihosocijalno zdravlje pojedinaca, što ga može činiti ključnim čimbenikom u gotovo svim aspektima života. Zbog toga se istražuje njegov utjecaj u različitim situacijama, pa tako i u kontekstu obrazovanja. Istraživače je zanimalo koliko često nastavnici koriste humor $\mathrm{i}$ je li on povezan s pozitivnim obrazovnim ishodima. Iako nije lako procijeniti koliko često se humor koristi tijekom nastave, autori ranijih istraživanja su korištenjem metode opažanja te iskaza studenata utvrdili da je uporaba humora na fakultetu svakodnevna pojava, točnije da je prosječno korištenje humora otprilike svakih 15 - 20 minuta te da ga češće koriste muški nastavnici (Bryant, Crane, Comisky i Zillmann, 1980; Gorham i Christophel, 1990). U 
svom preglednom radu Banas, Dunbar, Rodriguez i Liu (2011) navode rezultate o još češćem korištenju nastavničkog humora u recentnijim istraživanjima, što potvrđuje i istraživanje Torok, McMorris i Lin (2004) u kojemu je čak 60 \% studenata iskazalo da nastavnik uvijek koristi humor, a za tvrdnju da su nastavnici zabavni i duhoviti čak ih je 70 \% označilo da se slaže. Također, Banas i dr. (2011) navode da u usporedbi s nastavnicima na fakultetu nastavnici srednjih i osnovnih škola koriste humor znatno manje jer smatraju da nije primjeren dobi učenika.

Wanzer, Frymier, Wojtaszczyk i Smith (2006) koristili su metodu opažanja i proveli analizu korištenja humora na nastavi. Na temelju rezultata podijelili su nastavnički humor na dva generalna faktora: prikladan i neprikladan. Prikladan humor je općenito humor koji nikoga ne vrijeđa i koji pridonosi dobroj atmosferi. To može biti tzv. vezani humor, koji je izravno vezan uz sadržaj predavanja, nevezani humor, koji nije vezan uz sadržaj predavanja, ali pridonosi dobroj atmosferi, samoporažavajući humor, koji uključuje šale, priče i komentare nastavnika na vlastiti račun i neplanirani humor, koji se dogodi slučajno jer je nastavnik, primjerice, napravio pogrešku. Neprikladan humor je onaj koji ne bi trebalo koristiti na nastavi jer ne pridonosi poboljšanju učenja sadržaja. To može biti uvredljiv humor, koji je izravno usmjeren na ismijavanje pojedinaca ili grupa te podcjenjivački humor, koji je usmjeren na podcjenjivanje pojedinog studenta ili studentice na predavanju ili nekih studentskih ponašanja.

Wanzer, Frymier i Irwin (2010) razvili su procesnu teoriju nastavničkog humora, kojom žele objasniti na koji način se humor na nastavi može percipirati i dovesti do različitih ishoda. Prema ovoj teoriji (Slika 1), student mora prepoznati iznenađenje ili kontradikciju (nekongruentnost) poruke koju šalje nastavnik kako bi obratio pažnju na sadržaj, riješio nekongruentnost i prepoznao sadržaj kao humorističan. Ako student ne razriješi kontradikciju koja je pred njega postavljena, proces staje i student ostaje zbunjen. Prikladnost humora je idući, ključan element, koji odlučuje hoće li humorističan sadržaj dovesti do pozitivnih ili negativnih ishoda, odnosno hoće li dovesti do pamćenja sadržaja, veće motivacije ili do osjećaja ljutnje, izoliranosti i smanjenja motivacije za učenjem. Na Slici 1 može se vidjeti da će prikladan tip humora dovesti do pozitivnih ishoda jer takav humor motivira studenta da se uključi u procesiranje 
humoristične poruke. S druge strane, neprikladan tip humora stvara negativan efekt u studenata zbog čega smanjuje motivaciju i mogućnost za pamćenjem sadržaja jer stvara distrakciju od sadržaja kolegija.

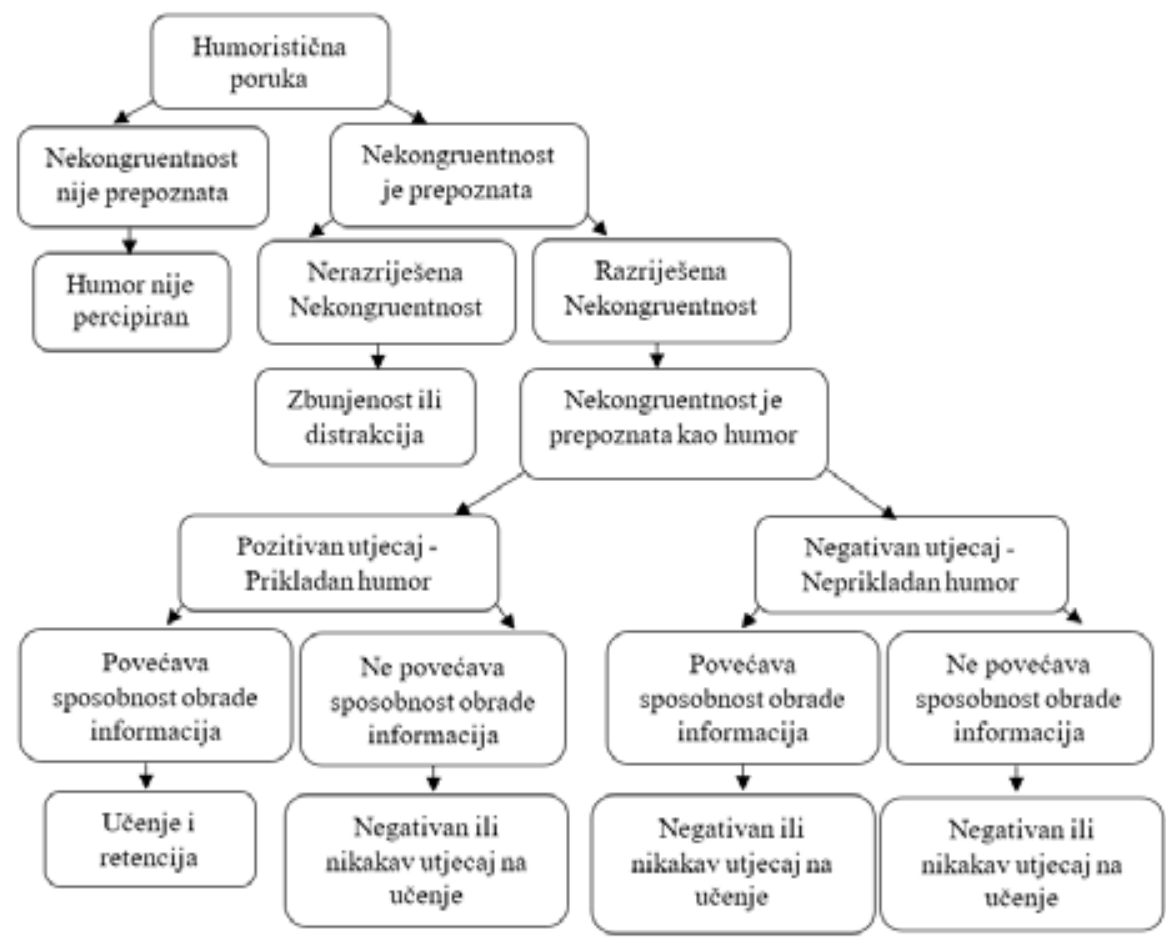

Slika 1. Procesna teorija nastavničkog humora (Wanzer, Frymier i Irwin, 2010)

Istraživana je i povezanost motivacije u učenju s nastavničkim humorom, a većina istraživanja nalazi pozitivnu korelaciju između prikladnog nastavničkog humora i motivacije u učenju (Banas i dr., 2011; Wanzer i dr., 2010). No pregledni rad Banas i dr. (2011) naglašava da rezultati nisu konzistentni zbog brojnih faktora koji utječu na motivaciju, kao i razlika u metodologiji istraživanja. Prema Pintrichu i Shunku (2002), motivacija je jedna od najvažnijih komponenti koja djeluje na ishode učenja, ali je i složena za mjerenje zbog utjecaja brojnih faktora (interesa, ciljeva, iskustva, prethodnog postignuća, karakteristika sadržaja koji se uči i dr.). Pintrich, Smith, Garcia i McKeachie (1991) kao motivacijske čimbenike učenja navode tri komponente: vrijednosti 
(intrinzičnu ciljnu orijentaciju, ekstrinzičnu ciljnu orijentaciju i vrijednost zadatka), očekivanja (uvjerenja o mogućnosti kontrole učenja i akademsku samoefikasnost) te afektivnu komponentu (ispitnu anksioznost). U ovome ćemo se istraživanju usmjeriti na vrijednost zadatka, akademsku samoefikasnost i ispitnu anksioznost. Vrijednost zadatka odnosi se na procjenu studenta koliko je zadatak zanimljiv, važan i koristan, a visoka vrijednost zadatka vodi visokoj uključenosti u učenje. Akademska samoefikasnost uključuje prosudbu o vlastitoj sposobnosti uspješnog izvršenja zadatka. Ispitna anksioznost sastoji se od dviju komponenata: kognitivne, koja uključuje zabrinutost i negativne misli koje ometaju izvođenje aktivnosti te emocionalne, koja se odnosi na fiziološku uzbuđenost, a negativno je povezana s očekivanjima i akademskim uspjehom (Pintrich i dr., 1991).

Većina istraživanja nastavničkog humora pokazala su povezanost korištenja humora s boljim ishodima učenja (npr. Hackathorn, Garczynski, Blankmeyer, Tennial i Solomon, 2011; McCabe, Sprute i Underdown, 2017; Wanzer i Frymier, 1999), što pruža dokaze o humoru kao potencijalno učinkovitoj komunikacijskoj strategiji u učionici. Činjenica da studenti na upitnicima redovito izvještavaju da im je smisao za humor jedna od najpoželjnijih kvaliteta uspješnog nastavnika (Hackathorn i dr., 2011; Torok i dr., 2004) govori o tome koliko im je on važan u obrazovnom procesu. Korištenje humora na nastavi povezano je s boljom percepcijom i evaluacijom nastavnika (Gorham i Christophel, 1990; Wanzer i Frymier, 1999; Wanzer i dr., 2010) te općenito boljom atmosferom i većom kohezijom na nastavi (Bergin, 1999; Torok i dr., 2004), pa i boljom atmosferom za vrijeme nastave na daljinu (Anderson, 2011; McCabe i dr., 2017). To može pomoći studentima pri smanjenju anksioznosti (Askildson, 2005; Chabeli, 2008) i dovesti do smanjenja ispitne anksioznosti (Berk, 2000), a time potencijalno poboljšati ispitne rezultate.

Važno je reći kako neće svaki stil humora nastavnika dovesti do navedenih pozitivnih ishoda. U skladu s ranije opisanom procesnom teorijom nastavničkog humora, pokazalo se da korištenje agresivnog, neprikladnog humora stvara neugodnu atmosferu za učenje (Chabeli 2008; Harris, 1989; Torok i dr., 2004), a povezano je i s nižom motivacijom za učenjem sadržaja koje nastavnik poučava (Chabeli, 2008; Gorham i Christophel, 1990). Kada nastavnici koriste 
neprikladan oblik humora, smanjuje se njihov kredibilitet u očima studenata (Gorham i Christophel, 1990). Wanzer i Frymier (1999) napominju da rezultati istraživanja nisu uvijek konzistentni te da humor neće uvijek dovesti do pozitivnih ili negativnih ishoda. Naime, ako je student duhovita osoba, tada će moći primijetiti nastavnički humor, usmjeriti pažnju te će moći doći do pozitivnih ili negativnih ishoda, a ako nije, neće primijetiti humor nastavnika (Gorham i Christophel, 1990). U dostupnoj literaturi nismo pronašli nijedno istraživanje koje povezuje stil humora studenta s čimbenicima vezanim uz nastavu.

Što se tiče povezanosti motivacijskih čimbenika i humora na nastavi, prema preglednom radu Banas i dr. (2011) korištenje prikladnog, pozitivnog humora povezano je s većom percipiranom motivacijom u učenju, a prikladan humor može povećati interes studenta i percepciju važnosti gradiva (Askildson, 2005). Dosadašnja istraživanja nisu ispitivala povezanost nastavničkog stila humora i akademske samoefikasnosti studenata, a pronađena je pozitivna korelacija između sveukupnog humora nastavnika i uključenosti studenata na nastavi (Evans-Palmer, 2009).

Većina istraživanja usmjerenih na proučavanje nastavničkog humora i pozitivnih ishoda koje donosi u obrazovnom kontekstu provedena je prije više desetaka godina zbog čega se javlja potreba za novijim rezultatima. Također, $\mathrm{u}$ Hrvatskoj do pisanja ovog rada ne postoji istraživanje koje ispituje navedenu temu. Stoga smo proveli istraživanje koje se bavilo ovim aspektima korištenja humora u obrazovnom kontekstu.

Cilj ovog istraživanja bio je ispitati doprinos stila humora sveučilišnih nastavnika (prikladni i neprikladni) i stila humora studenata (afilijativni, agresivni, samoporažavajući i samopoboljšavajući) u objašnjenju evaluacije nastavnika i motivacijskih čimbenika: ispitne anksioznosti, vrijednosti zadatka te akademske samoefikasnosti studenata.

Na temelju procesne teorije nastavničkog humora i prethodnih istraživanja postavili smo sljedeće hipoteze:

H1: Očekujemo da će prikladan humor nastavnika biti pozitivan, a neprikladan humor nastavnika negativan prediktor evaluacije nastavnika. Ne 
očekujemo da će stilovi humora studenata biti statistički značajni prediktori evaluacije nastavnika.

H2: Očekujemo da će agresivni i samoporažavajući stil humora studenata te neprikladan humor nastavnika biti pozitivni, a afilijativni i samopoboljšavajući stil humora studenata i prikladan humor nastavnika negativni prediktori ispitne anksioznosti.

H3: Očekujemo da će afilijativni i samopoboljšavajući stil humora studenata te prikladan humor nastavnika biti pozitivni, a agresivni i samoporažavajući stil humora studenata te neprikladan humor nastavnika negativni prediktori vrijednosti zadatka.

H4: Očekujemo da će afilijativni i samopoboljšavajući stil humora studenata te prikladan humor nastavnika biti pozitivni, a agresivni i samoporažavajući stil humora studenata te neprikladan humor nastavnika negativni prediktori akademske samoefikasnosti.

\section{Metodologija}

\section{Postupak}

Istraživanje je provedeno mrežnim putem, a podaci su prikupljani u razdoblju od tri tjedna u ožujku 2020. godine. S obzirom na to da istraživanje zahtijeva da se sudionik prisjeti zadnjeg ispita kojemu je prisustvovao i osobe koja je vodila većinu nastave, podatke smo započeli prikupljati tijekom ožujka jer su prije toga na svim fakultetima završili ispitni rokovi. Za provedbu istraživanja online odlučili smo se zbog početka pandemije virusa COVID-19.

Mrežni upitnik kreiran je preko platforme Google Forms. U istraživanju je korištena neprobabilistička metoda uzorkovanja, odnosno elementi tehnike „snježne grude“. Pozivnica na upitnik podijeljena je sudionicima putem stranica i grupa na Facebooku u kojima su većinom studenti (npr. Studentski dom Stjepan Radić, Tražim nudim/studentski posao itd.). Naslovna stranica upitnika sadržavala je uputu, obavijest o potpunoj anonimnosti, korištenju podataka u istraživačke svrhe, informaciju o tome da je sudionik slobodan odustati od ispunjavanja upitnika u bilo kom trenutku i molbu da upitnik proslijedi i svojim 
TEA FILEŠ, NINA PAVLIN-BERNARDIĆ: STILOVI HUMORA SVEUČILIŠNIH NASTAVNIKA KAO PREDIKTORI EVALUACIJE NASTAVNIKA I MOTIVACIJSKIH ČIMBENIKA U STUDENATA

prijateljima koji su studenti. Ispunjavanje cijelog upitnika trajalo je otprilike 15 do 20 minuta po sudioniku.

\section{Sudionici}

U istraživanju je sudjelovalo ukupno 290 studenata (27,9 \% muškaraca). Raspon dobi kretao se između 19 i 32 godine, a prosječna dob sudionika je 22,4 godine. Većina sudionika je bila s fakulteta iz područja društvenih znanosti $(53,1 \%)$ i tehničkih znanosti $(20 \%)$, a ostali su bili s fakulteta iz područja humanističkih znanosti, biomedicine i zdravstva, prirodnih znanosti i biotehničkih znanosti. Studenata prve godine fakulteta je bilo 13,8 \%, druge godine 15,2 \%, treće godine $17,9 \%$, četvrte godine $30 \%$, pete godine $14,5 \%$, a apsolvenata $8,6 \%$.

\section{Mjerni instrumenti}

Na početku upitnika sudionicima je dana opća uputa o odabiru nastavnika za kojeg će davati procjene. Navedeno je da se prisjete zadnjeg ispita koji su polagali i da procjene daju za osobu koja im je održavala većinu nastave tog kolegija (asistenta, docenta ili profesora). Također je navedeno da se, ako nisu prisustvovali većini nastave toga kolegija, prisjete ispita koji su polagali prije toga i osobe koja je održavala većinu nastave tog kolegija te da daju procjenu za nju/njega. Upitnik je sadržavao sljedeće skale:

Skala nastavničkog humora (engl. Instructor Humor Scale (IHC), Frymier, Wanzer i Wojtaszczyk, 2008).

Ovaj instrument namijenjen je mjerenju specifičnih tipova humora nastavnika. Temelji se na istraživanju Wanzer i dr. (2006), koji su identificirali različite tipove humora koje nastavnici koriste tijekom predavanja te su odredili dva glavna faktora - prikladni i neprikladni humor.

Originalna skala sastoji se od 25 čestica, a u svrhu našeg istraživanja prevedena je na hrvatski jezik. Kako bi prijevod bio što vjerniji originalu, provedena je provjera jezične ekvivalentnosti tako da su dvije različite osobe prevele upitnik s engleskog jezika na hrvatski te s hrvatskog prijevoda na engleski. Tri osobe su dobile prevedenu verziju upitnika kako bismo provjerili razumijevanje 
pojedine čestice te je na temelju njihovih nezavisnih povratnih informacija napravljena konačna verzija hrvatske inačice upitnika.

Nakon što su sudionici pročitali opću uputu o odabiru nastavnika za kojeg će raditi procjenu, zadatak im je bio da na skali od 1 (nikada) do 5 (gotovo uvijek) procijene u kolikoj se mjeri nastavnik ponaša na određeni način (npr. Koristi humor vezan uz gradivo kolegija ili Koristi duhovite materijale (npr. slike, video) kako bi ilustrirao/ilustrirala neki pojam ili kao primjer). Faktorska analiza metodom glavnih komponenti s rotacijom varimax ukazuje na dvofaktorski model. Četiri čestice su bile dvostruko zasićene te smo u daljnjoj analizi koristili ukupno 21 česticu. Na prikladni tip humora odnosi se 12 čestica, a na neprikladni 9 čestica. Ukupan rezultat za pojedini tip humora računa se kao aritmetička sredina procjena. S obzirom na to da faktorskom analizom nije demonstrirana tau-ekvivalentnost, pouzdanost tipa unutarnje konzistencije izražena je McDonaldovim omega koeficijentom te iznosi za prikladni oblik humora $\omega=.91$, a za neprikladni $\omega=.89$.

Upitnik motiviranih strategija za učenje (The Motivated Strategies for Learning Questionnaire (MSLQ); Pintrich i dr., 1991).

Za potrebe ovog istraživanja iz upitnika MSLQ-a korištene su skale vrijednosti zadatka, akademske samoefikasnosti i ispitne anksioznosti. Skala vrijednosti zadatka sastoji se od 6 čestica koje se odnose na percepciju koju student ima o vlastitim interesima, važnosti i korisnosti kolegija (npr. Važno mi je da naučim gradivo ovog kolegija). Skala akademske samoefikasnosti sastoji se od 8 čestica koje upućuju na očekivanje uspjeha u izvršavanju obveza kolegija (npr. Siguran/Sigurna sam da mogu naučiti najteže dijelove literature za ovaj kolegij). Skala ispitne anksioznosti sastoji se od 5 čestica koje se odnose na kognitivni i emocionalni aspekt ispitne anksioznosti (npr. Dok pišem test mislim o tome kako loše napredujem u odnosu na druge studente). Kognitivni aspekt se odnosi na zabrinutost, odnosno negativne misli koje utječu na lošu izvedbu, a emocionalni na afektivnu i fiziološku pobuđenost tijekom ispita.

$\mathrm{Na}$ svakoj skali sudionik treba označiti stupanj slaganja $\mathrm{s}$ pojedinom tvrdnjom, od 1 (uopće se ne slažem) do 7 (u potpunosti se slažem). Ukupan 
TEA FILEŠ, NINA PAVLIN-BERNARDIĆ: STILOVI HUMORA SVEUČILIŠNIH NASTAVNIKA KAO PREDIKTORI EVALUACIJE NASTAVNIKA I MOTIVACIJSKIH ČIMBENIKA U STUDENATA

rezultat za svaku skalu izražava se kao aritmetička sredina odgovora na čestice. Rezultati pouzdanosti unutarnje konzistencije izražene koeficijentom Cronbachovim alpha u našem istraživanju iznose: vrijednost zadatka $\alpha=.93$, akademska samoefikasnost $\alpha=.91 \mathrm{i}$ ispitna anksioznost $\alpha=.82$.

Upitnik evaluacije nastavnika (Ljubotina, 2006).

Upitnik je razvijen s ciljem vrednovanja kvalitete nastave na Sveučilištu u Zagrebu, koje je provodio Centar za psihodijagnostičke instrumente Filozofskog fakulteta u suradnji s Uredom za upravljanje kvalitetom Sveučilišta u Zagrebu. Za potrebe ovog istraživanja korištena je supskala koja se odnosi na karakteristike rada nastavnika (npr. Kroz nastavu pokazuje dobro poznavanje sadržaja kolegija), a sastoji se od 14 čestica koje mjere jedan generalni faktor. Ukupni rezultat se računa kao aritmetička sredina odgovora na čestice. Sudionici odgovaraju na pitanja na skali od 1 (nikako se ne slažem) do 5 (u potpunosti se slažem). Pouzdanost upitnika u ovom istraživanju iznosi $\alpha=.93$.

Upitnik stilova humora (Humor Styles Questionnaire (HSQ), Martin i dr., 2003).

Ovaj upitnik mjeri četiri stila humora: afilijativni (npr. Ne moram se puno truditi da nasmijem ljude. Izgleda da sam prirodno duhovita osoba), samopoboljšavajući (npr. Ako sam uzrujan/uzrujana ili nesretan/nesretna, obično pokušavam misliti na zabavne situacije kako bih se bolje osjećao/osjećala), agresivni (npr. Kad netko napravi grešku, često ga zadirkujem zbog toga) i samoporažavajući (npr. Dozvoljavam ljudima da se smiju na moj račun više nego bi trebalo).

Upitnik se odnosi na procjenu vlastitog humora zbog čega su u tom dijelu sudionici dobili uputu da se tvrdnje odnose na njih i na njihovo ponašanje vezano uz humor. U ovom je istraživanju korištena verzija upitnika preuzeta iz rada u kojem je preveden na hrvatski jezik (Tubin, 2011). Sastoji se od ukupno 32 čestice, pri čemu je svaki stil ispitan s 8 čestica na koje sudionici odgovaraju na skali od 1 (u potpunosti se ne slažem) do 7 (u potpunosti se slažem). Ukupan 
rezultat za svaki stil humora računa se kao aritmetička sredina čestica koje mu pripadaju. Pouzdanosti tipa unutarnje konzistencije u našem istraživanju iznose: afilijativni stil $\alpha=.78$, samopoboljšavajući stil $\alpha=.78$, agresivni stil $\alpha=.69$ i samoporažavajući stil $\alpha=.81$.

Uz navedeno, sudionici su u upitniku označili i sociodemografske podatke: spol, dob, područje studija i godinu studiranja te su označili spol nastavnika/ nastavnice.

\section{Rezultati}

Procjene sudionika odnosile su se na 52,4 \% nastavnika muškog i 47,6 \% ženskog spola. U Tablici 1 prikazani su deskriptivni podaci za ispitivane varijable. Za većinu varijabli indeksi asimetričnosti bili su manji od $+/-2$, a indeksi spljoštenosti manji od $+/-7$ pa se distribucije mogu smatrati normalnima (Ryu, 2011). Jedino je za varijablu neprikladnog humora nastavnika pokazana pozitivna asimetričnost. Iako skala neprikladnog humora odstupa od normaliteta, to je u manjoj mjeri dozvoljeno (Howell, 2002), a i s obzirom na dovoljno velik broj ispitanika, koristili smo parametrijske analize podataka.

Tablica 1. Deskriptivni podaci ispitanih varijabli $(\mathrm{N}=290)$

\begin{tabular}{lllllll}
\hline & $M$ & $S D$ & $\min$ & $\max$ & $A$ & $S$ \\
\hline afilijativni stil & 5,57 & 5,70 & 2,25 & 7,00 & -.724 & .182 \\
samopoboljšavajući stil & 4,65 & 4,75 & 1,13 & 7,00 & -.279 & .042 \\
agresivni stil & 3,30 & 3,25 & 1,00 & 6,50 & .228 & .005 \\
samoporažavajući stil & 3,47 & 3,50 & 1,00 & 6,63 & .223 & -.316 \\
\hline ispitna anksioznost & 3,96 & 1,47 & 1 & 7 & .028 & -.783 \\
vrijednost zadatka & 5,25 & 1,51 & 1 & 7 & -.811 & -.003 \\
akademska samoefikasnost & 5,38 & 1,23 & 1,63 & 7 & -.726 & .041 \\
\hline prikladan humor nastavnika & 2,51 & 0,89 & 1 & 5 & .333 & -.407 \\
neprikladan humor nastavnika & 1,19 & 0,49 & 1 & 5 & 4.459 & 24.199 \\
\hline evaluacija nastavnika & 4,21 & 0,75 & 1,27 & 5 & -1.170 & 1.092 \\
\hline
\end{tabular}

Legenda. $\mathrm{A}=$ indeks asimetričnosti, $\mathrm{S}=$ indeks spljoštenosti

U Tablici 2 prikazane su korelacije ispitivanih varijabli. 


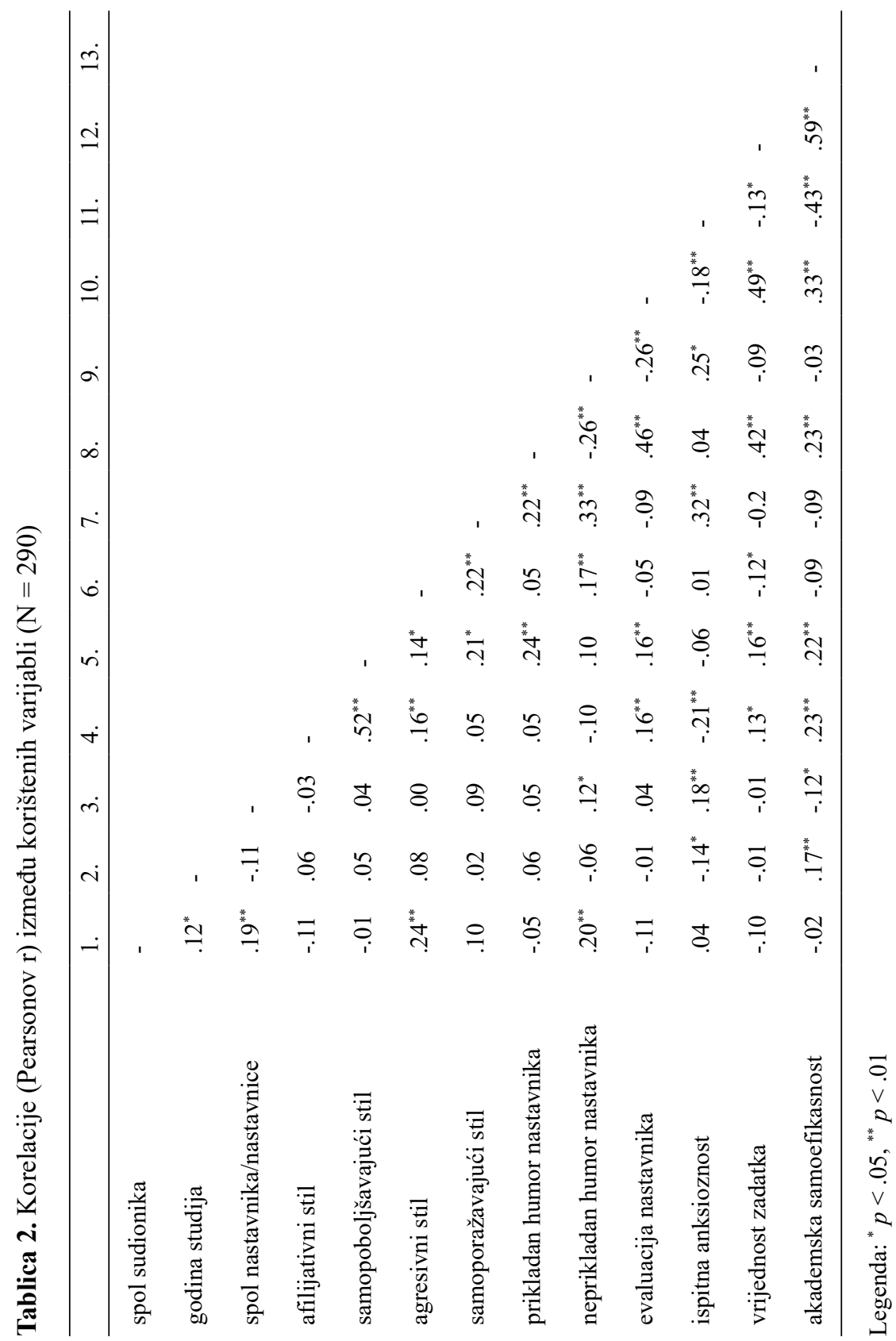


Provedene su četiri hijerarhijske analize s istim prediktorima: kontrolnim varijablama (spolom sudionika, godinom studija i spolom nastavnika/nastavnice), samoprocijenjenim stilom humora studenata (afilijativnim, samopoboljšavajućim, agresivnim i samoporažavajućim) te vrstom nastavničkog humora (prikladnim i neprikladnim humorom), dok su kriteriji bili evaluacija nastavnika i motivacijski čimbenici (ispitna anksioznost, vrijednost zadatka i akademska samoefikasnost). U analizu su u prvom koraku uključene kontrolne varijable, u drugom koraku vlastiti stilovi humora, a u trećem nastavnički stilovi humora.

U Tablici 3 prikazani su rezultati hijerarhijske regresijske analize s evaluacijom nastavnika kao kriterijem. Prvi korak nije se pokazao statistički značajnim. U drugom koraku dodani su vlastiti stilovi humora, pri čemu model postaje značajnim, no objašnjava svega 3,6 \% varijance evaluacije nastavnika. U trećem koraku je dodan nastavnički tip humora koji statistički značajno povećava postotak objašnjene varijance, točnije za 30,8 \%, što čini ukupno 34,4 \% objašnjene varijance evaluacije nastavnika. Značajan pozitivan prediktor evaluacije nastavnika u ovom istraživanju je prikladan nastavnički humor, a negativan prediktor neprikladan humor nastavnika, pri čemu najveći samostalni doprinos ima prikladan stil humora nastavnika, koji objašnjava $29,16 \%$ varijance. 


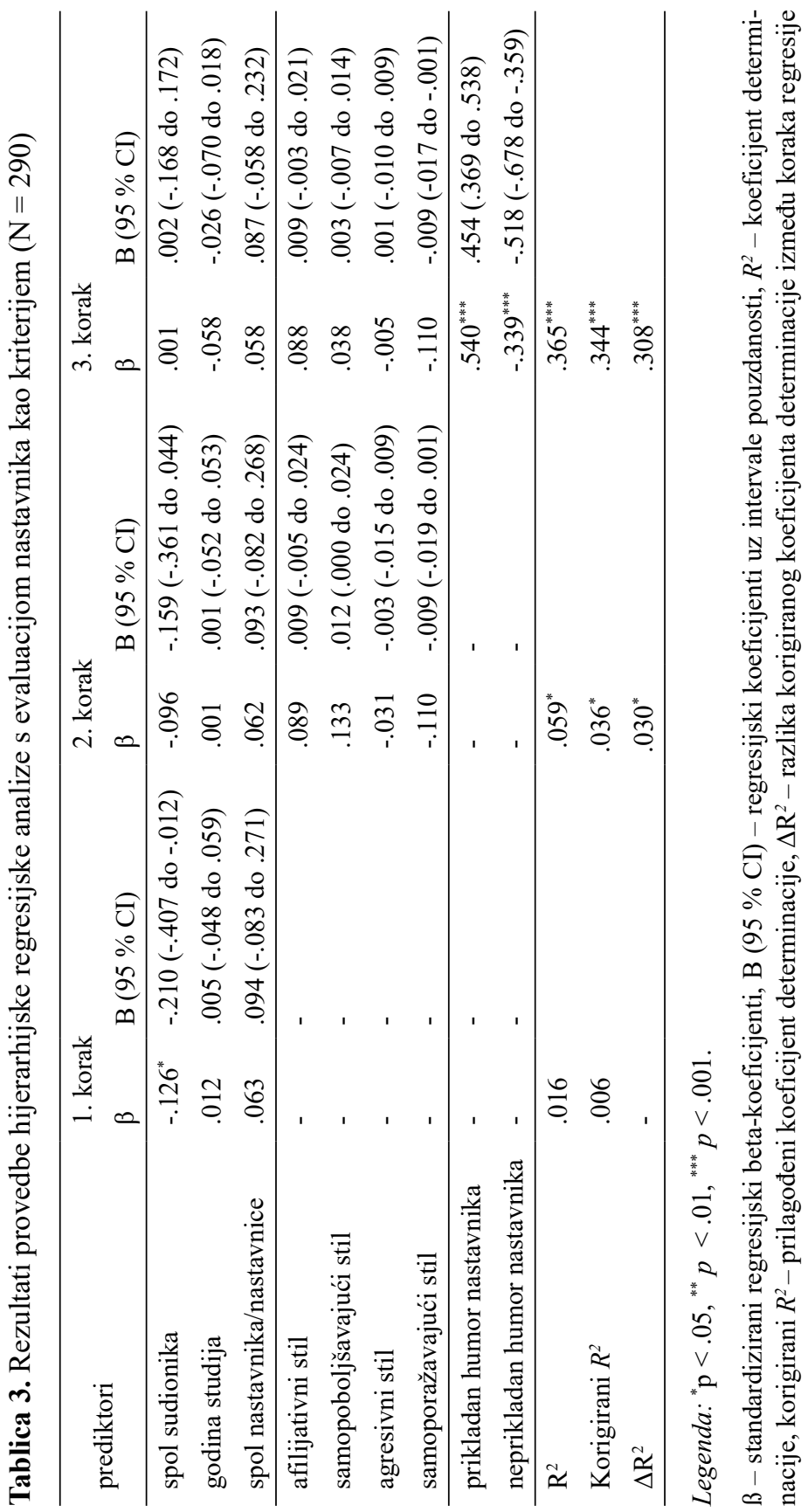


Rezultati hijerarhijskih regresijskih analiza u kojima su kao kriteriji korišteni motivacijski čimbenici (ispitna anksioznost, vrijednost zadatka i akademska samoefikasnost) prikazani su u Tablici 4. Kada je ispitna anksioznost korištena kao kriterij, kontrolne varijable objasnile su 3,7 \% varijance. Dodavanjem vlastitih stilova humora u drugom koraku dodatno je objašnjeno još $13,2 \%$ varijance. Dodavanjem nastavničkog humora u trećem koraku ne dolazi do statistički značajne promjene u objašnjenju varijance ispitne anksioznosti te je ukupan postotak objašnjene varijance $16,4 \%$. Najveći samostalni doprinos $u$ objašnjenju varijance ispitne anksioznosti imaju vlastiti samoporažavajući stil humora, zatim afilijativni stil te spol nastavnika/nastavnice.

U slučaju kada je vrijednost zadatka korištena kao kriterij, prvi korak hijerarhijske analize nije se pokazao statistički značajnim. U drugom koraku, dodavanjem vlastitog stila humora objašnjeno je svega 2,9\% varijance vrijednosti zadatka. Uvođenjem nastavničkog humora u trećem koraku taj postotak objašnjene varijance raste za 18,9 \%, čime je ukupno objašnjeno 21,8 \% varijance. Samopoboljšavajući stil u tom koraku prestaje biti značajnim prediktorom zbog čega postoji mogućnost da je vrsta nastavničkog humora medijator odnosa samopoboljšavajućeg vlastitog stila humora i vrijednosti zadatka. Pokazalo se i da viši prikladan humor nastavnika te niži neprikladan humor nastavnika predviđaju višu vrijednost zadatka, pri čemu najveći samostalni doprinos ima prikladan nastavnički humor.

Kada je akademska samoefikasnost korištena kao kriterij, prvi je korak statistički značajan, a pozitivan prediktor akademske samoefikasnosti je viša godina studija. Kontrolnim varijablama objašnjeno je svega $2,8 \%$ varijance akademske samoefikasnosti. U drugom koraku, dodavanjem vlastitog stila humora objašnjava se dodatnih $8,2 \%$ varijance akademske samoefikasnosti. U trećem koraku, dodavanjem nastavničkih stilova humora objašnjava se dodatnih $4,4 \%$ varijance te je objašnjeno ukupno $16,4 \%$ varijance akademske samoefikasnosti u studenata. Najveći samostalni doprinos ima prikladan humor nastavnika, čiji viši rezultat predviđa višu akademsku samoefikasnost. Zanimljivo je da uvođenjem vrste nastavničkog humora u trećem koraku samoporažavajući vlastiti stil humora postaje statistički značajnim negativnim prediktorom, a samopoboljšavajući stil prestaje biti statistički značajnim prediktorom. Uvidom u korelacijsku matricu možemo vidjeti da je samopoboljšavajući stil statistički značajno povezan s akademskom samoefikasnošću, a agresivni i samoporažavajući stil nemaju statistički značajne bivarijatne korelacije s ovim kriterijem, no predstavljaju statistički značajne prediktore. Moguće je da se radi o supresorskom efektu, no efekti su mali. 
TEA FILEŠ, NINA PAVLIN-BERNARDIĆ: STILOVI HUMORA SVEUČILIŠNIH NASTAVNIKA KAO PREDIKTORI EVALUACIJE NASTAVNIKA I MOTIVACIJSKIH ČIMBENIKA U STUDENATA

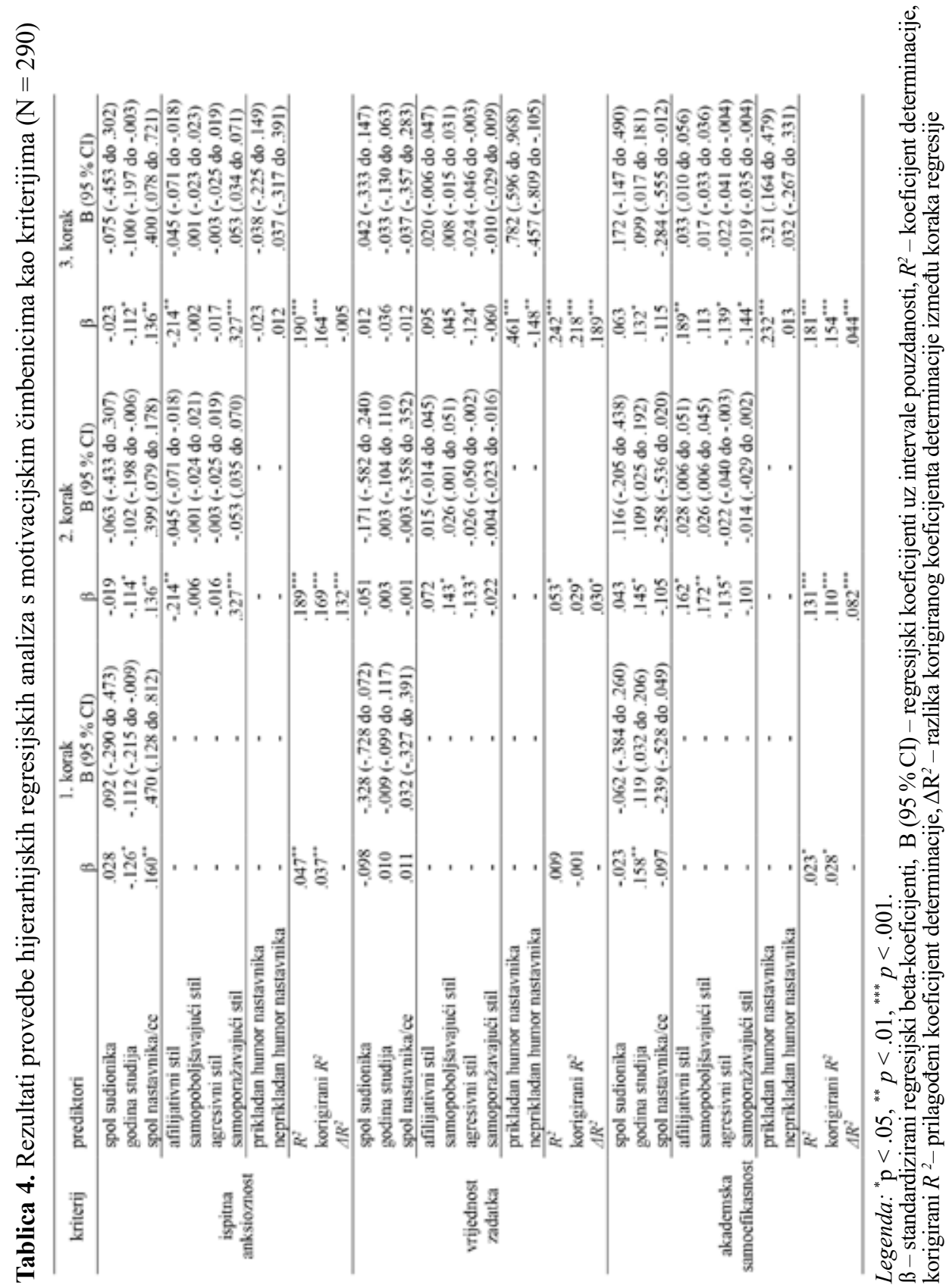




\section{Rasprava}

Cilj ovog istraživanja bio je ispitati doprinose li stil humora studenata i stil humora njihovih nastavnika objašnjenju evaluacije nastavnika i motivacijskih čimbenika (ispitne anksioznosti, vrijednosti zadatka i akademske samoefikasnosti) u studenata.

Deskriptivni podaci koje smo dobili pokazuju da sveučilišni nastavnici tijekom predavanja uglavnom koriste prikladan humor, dok neprikladan humor koriste rijetko. Ovaj nalaz u skladu je s dosadašnjim istraživanjima, koja pokazuju da nastavnici relativno često koriste neki prikladan oblik humora na nastavi (šale, prikazivanje različitih duhovitih materijala i slično), a manje onaj koji se smatra agresivnim, odnosno neprikladnim (Banas i dr., 2011; Wanzer, Frymier, Wojtaszczyk i Smith, 2006). Što se tiče studentskih samoprocjena vlastitog stila humora, iz naših se rezultata može vidjeti da studenti najviše koriste afilijativni stil humora, a najmanje agresivni. Slični rezultati dobiveni su i u istraživanju Tubin (2011).

Kada je u hijerarhijskoj regresijskoj analizi kao kriterij korištena evaluacija nastavnika, naša postavljena hipoteza je potvrđena. Prikladan humor nastavnika se pokazao pozitivnim, a neprikladan humor nastavnika negativnim prediktorom evaluacije nastavnika. Dobiveni rezultati su u skladu s prethodnim istraživanjima (Gorham i Christophel, 1990; Wanzer i Frymier, 1999; Wanzer i dr., 2010). S obzirom na to da se evaluacija nastavnika odnosi isključivo na karakteristike nastavnika i na kvalitetu provođenja nastave, nismo očekivali da je povezana s vlastitim stilom humora studenata jer studenti procjenjuju realne i vidljive karakteristike nastave $i$ izvedbe nastavnika, na što njihov stil humora ne utječe. Taj dio hipoteze također je potvrđen. Pokazalo se i da stil humora nastavnika objašnjava 30,8 \% varijance evaluacije nastavnika povrh drugih korištenih varijabli zbog čega navedeni nalaz može poslužiti nastavnicima kako bi povećali zadovoljstvo studenata na predavanju.

Kada je ispitna anksioznost korištena kao kriterij, hipoteza je djelomično potvrđena. U prvom koraku, u kojemu su u model uključene samo kontrolne varijable, objašnjeno je 3,7 \% varijance ispitne anksioznosti. Rezultati pokazuju da niža godina studija i muški spol nastavnika predviđaju višu ispitnu anksioznost. Moguće objašnjenje je to što studenti nižih godina vjerojatno nemaju 
još toliko iskustva s polaganjem ispita na fakultetu pa zbog nepredvidivosti ispitne situacije mogu osjećati veću anksioznost od kolega s viših godina. Većina istraživanja ispitne anksioznosti proučavala su odnos roda studenta/studentice i ispitne anksioznosti (npr. Devine, Fawcett, Szücs i Dowker, 2012; Everson, Millsap i Rodriguez, 1991) te se pokazalo da studentice općenito izvještavaju o višoj ispitnoj anksioznosti, a posebno kada je na ispitu prisutan muški nastavnik (Martin i Marsh, 2005). U našem istraživanju u uzorku je bilo 72,1 \% žena pa je moguće da je zbog toga došlo do rezultata da muški spol nastavnika predviđa višu ispitnu anksioznost. No treba napomenuti da je bivarijatna korelacija ovih varijabli niska.

Potvrđeno je da je afilijativni stil humora studenata negativan prediktor, a samoporažavajući stil pozitivan prediktor njihove ispitne anksioznosti. Naime, cilj afilijativnog stila humora je zabavljanje drugih i smanjivanje vlastite napetosti pa pomaže i u smanjenju ispitne anksioznosti. Samoporažavajući stil uključuje ismijavanje i degradiranje sebe kako bi se poboljšao odnos s drugima te uključuje obrambeni mehanizam sakrivanja negativnih osjećaja i „bježanja od problema“" (Martin i dr., 2003) pa je vjerojatno stoga i povezan s višom ispitnom anksioznošću. Zanimljivo je da se samopoboljšavajući i agresivni stil humora studenata nisu pokazali značajnim prediktorima, što nije u skladu s postavljenom hipotezom. Ni bivarijatne korelacije ovih dvaju stilova s ispitnom anksioznošću nisu statistički značajne pa je moguće da ih studenti ne koriste pri smanjenju ispitne anksioznosti, što je potrebno provjeriti i u budućim istraživanjima.

Iako vlastiti stilovi humora objašnjavaju svega 13,2 \% ispitne anksioznosti, koristan je nalaz da takva osobna karakteristika ima statistički značajan doprinos objašnjenju ispitne anksioznosti. Svakako je potrebno istražiti koliki je taj doprinos ako se kao prediktori uključe i varijable vezane uz kolegij koji nastavnik drži (primjerice, težina kolegija, interes za kolegij i slično).

U trećem koraku analize, uvrštavanjem nastavničkog humora, nije došlo do statistički značajne promjene u modelu. Drugim riječima, vrsta nastavničkog humora nije se pokazala statistički značajnim prediktorom ispitne anksioznosti. Navedeno nije u skladu s postavljenom hipotezom. Moguće objašnjenje nepostojanja povezanosti između nastavničkog humora i ispitne anksioznosti 
u ovom istraživanju je to što se procjena nastavničkog stila humora odnosila na onaj korišten na nastavi, a ne na samom ispitu. Naime, u istraživanju Berk (2000) humorističan sadržaj je uvršten u uputu i ispitna pitanja te je tako humor smanjio ispitnu anksioznost i poboljšao izvedbu. Također, studenti osjećaju višu ispitnu anksioznost pri usmenim ispitima nego pri pisanim ispitima (Laurin-Barantke, Hoyer, Fehm i Knappe, 2016), a u našem istraživanju nismo ispitali za koju vrstu ispita su studenti davali procjene, što bi korisno bilo ispitati u budućim istraživanjima.

Što se tiče doprinosa vlastitog i nastavničkog humora u objašnjenju vrijednosti zadatka, postavljene hipoteze su djelomično potvrđene. Samopoboljšavajući stil humora studenata pokazao se pozitivnim, a agresivni stil negativnim prediktorom vrijednosti zadatka, no afilijativni i samoporažavajući stil nisu pokazali statistički značajan doprinos. Naši rezultati pokazuju da samoprocijenjeni stilovi humora studenata objašnjavaju vrlo mali dio varijance vrijednosti zadatka. Dodavanjem vrste nastavničkog humora u trećem koraku, samopoboljšavajući vlastiti stil prestaje biti statistički značajan prediktor vrijednosti zadatka.

Dosadašnja istraživanja pokazala su da je prikladan humor nastavnika pozitivno povezan, a neprikladan negativno povezan s interesom i percepcijom važnosti gradiva učenika i studenata (Askildson, 2005; Banas i dr., 2011). Takav je rezultat dobiven i u našem istraživanju. Prema procesnoj teoriji nastavničkog humora (Wanzer i dr., 2010), prikladan ili neprikladan humor povećava, odnosno smanjuje učenje i retenciju gradiva, kao i motivaciju za učenjem, što se u našem istraživanju pokazalo na varijabli vrijednosti zadatka kao mjeri motivacije za učenjem. Ovaj je nalaz koristan za nastavnike jer pokazuje da, iako je ovaj doprinos ograničen, korištenjem humora na nastavi mogu donekle doprinijeti percepciji važnosti, interesa i korisnosti vlastitog kolegija u studenata.

Slični su rezultati dobiveni kada smo kao kriterij koristili još jednu mjeru motivacije za učenjem, akademsku samoefikasnost. Hipoteza je djelomično potvrđena te je afilijativni stil humora pozitivan prediktor, a agresivni i samoporažavajući stilovi su negativni prediktori akademske samoefikasnosti. Prikladan nastavnički humor se pokazao pozitivnim prediktorom, što znači da korištenje pozitivnog, prikladnog humora na nastavi pridonosi percepciji studenata $\mathrm{o}$ mogućnosti savladavanja kolegija i dobivanja dobre ocjene. S druge strane, 
neprikladan humor se nije pokazao statistički značajnim, što nije u skladu s našom hipotezom. S obzirom na pretpostavke procesne teorije nastavničkog humora, korištenje neprikladnog humora na nastavi dovodi do negativnih ili nikakvih efekata na retenciju i učenje. Prema našem nalazu, postoji mogućnost da je procesna teorija nastavničkog humora primjenjiva i na akademsku samoefikasnost. Naime, ako student usmjeri pažnju na kontradiktornost i razriješi ju kao prikladan humor, doći će do učenja, zbog čega bi se moglo povećati i očekivanje uspjeha, kao i prosudba o vlastitoj sposobnosti uspješnog izvršenja zadatka. Ako kontradiktornost razriješi kao neprikladan humor, prema teoriji neće doći do učenja sadržaja pa je moguće da učinka na percepciju akademske samoefikasnosti neće biti. Navedeni odnos je potrebno istražiti u budućim istraživanjima, kao i ostale čimbenike koji mogu objasniti taj odnos (npr. interes za kolegij, osobine studenata i dr.).

Ovo istraživanje ima određene metodološke nedostatke. Uzorak je neprobabilistički, a korišteni su neki elementi tehnike „snježne grude“. Prikupljanjem putem grupa i stranica na Facebooku izostavljeni su studenti koji nisu u navedenim grupama ili uopće ne koriste Facebook. Također, u uzorku je puno veći broj sudionica, što je česta karakteristika istraživanja online (Smith, 2008). Struktura uzorka prema području fakulteta je neravnomjerna (najviše je sudionika s fakulteta društvenih znanosti, a zatim tehničkih znanosti) jer je moguće da je studentima s tih fakulteta tema bila zanimljivija ili je više njih bilo $u$ grupama na Facebooku u koje je poslan upitnik, kao i to da su zatim vjerojatno češće prosljeđivali poveznicu na upitnik prijateljima s istog fakulteta. Moguće je i da su upitnik odabrali ispunjavati studenti kojima je humor u nastavi bitniji. Stoga naš uzorak nije reprezentativan za populaciju studenata u Hrvatskoj, a mogućnost generalizacije dobivenih rezultata je ograničena. Uz to, kao što smo ranije napomenuli, pri procjeni ispitne anksioznosti nismo ispitali radi li se o pisanim ili usmenim ispitima, a procjenjivani humor nastavnika odnosio se na nastavu, ne na ispite, što bi u budućim istraživanjima trebalo uzeti u obzir.

Nalazi istraživanja imaju i praktične implikacije na nastavu. Iako doprinosi vlastitog stila humora i stila humora nastavnika u objašnjenju varijance motivacijskih čimbenika nisu veliki, korištenje pozitivnog stila humora te nastavnikovo korištenje prikladnog stila humora može imati pozitivne ishode za studente. 
Također, prikladan stil humora samostalno objašnjava 29,16 \% varijance evaluacije nastavnika. Kako bi došlo do pozitivnih ishoda učenja, nastavnici bi prvenstveno trebali koristiti humor koji je vezan uz gradivo kolegija te duhovite materijale kao ilustraciju gradiva.

\section{Zaključak}

Cilj ovog istraživanja bio je ispitati doprinos stila humora studenata i nastavničkog stila humora u objašnjenju evaluacije nastavnika i motivacijskih čimbenika u studenata (ispitne anksioznosti, vrijednosti zadatka i akademske samoefikasnosti). Kada je evaluacija nastavnika korištena kao kriterij, dobiveno je da viši prikladni humor nastavnika, a niži neprikladni humor nastavnika predviđaju višu evaluaciju nastavnika.

Što se tiče motivacijskih čimbenika, niži afilijativni i viši samoporažavajući stil humora studenata predviđaju višu ispitnu anksioznost, dok stilovi humora nastavnika nisu bili statistički značajni prediktori. Višu vrijednost zadatka predviđaju niži agresivni i viši samopoboljšavajući stil humora studenata te viši prikladni i niži neprikladni stil humora nastavnika. Viši afilijativni i samopoboljšavajući stil te niži agresivni stil humora studenata, kao i viši prikladan humor nastavnika predviđaju višu akademsku samoefikasnost studenata. Treba napomenuti da nisu sve postavljene hipoteze potvrđene te da su doprinosi stila humora studenata i njihovih procjena stila humora nastavnika u objašnjenju varijance motivacijskih čimbenika mali. Ipak, istraživanje ukazuje na to da je humor poželjan u obrazovnom kontekstu te upućuje na korisnost prikladnog i pozitivnog humora na nastavi i na izbjegavanje njegovih neprikladnih oblika. Dobiveni rezultati su dijelom u skladu s procesnom teorijom nastavničkog humora (Wanzer, Frymier i Irwin, 2010), no potrebne su daljnje provjere ove teorije u kontekstu realnih situacija učenja i retencije materijala. 
TEA FILEŠ, NINA PAVLIN-BERNARDIĆ: STILOVI HUMORA SVEUČILIŠNIH NASTAVNIKA KAO PREDIKTORI EVALUACIJE NASTAVNIKA I MOTIVACIJSKIH ČIMBENIKA U STUDENATA

\section{Literatura}

Abel, M. H. (2002). Humor, stress, and coping strategies. Humor, 15(4), 365-381. DOI: http://dx.doi.org/10.1515/humr.15.4.365

Anderson, D. G. (2011). Taking the "distance" out of distance education: A humorous approach to online learning. Journal of Online Learning and Teaching, 7(1), 74-81.

Askildson, L. (2005). Effects of humor in the language classroom: Humor as a pedagogical tool in theory and practice. Journal of Second Language Acquisition and Teaching, 12, 45-61.

Banas, J. A., Dunbar, N., Rodriguez, D. i Liu, S. J. (2011). A review of humor in educational settings: Four decades of research. Communication Education, 60(1), 115-144. DOI: http://dx.doi.org/10.1080/03634523.2010.496867

Bergin, D. A. (1999). Influences on classroom interest. Educational Psychologist, 34, 87-98. DOI: http://dx.doi.org/10.1207/s15326985ep3402_2

Berk, R. A. (2000). Does humor in course tests reduce anxiety and improve performance?. College Teaching, 48(4), 151-158. DOI: http://dx.doi. org/10.1080/87567550009595834

Brozović, D. (2004). Hrvatska enciklopedija. Zagreb: Leksikografski zavod Miroslav Krleža.

Bryant, J., Crane, J. S., Cominsky, P. W. i Zillmann, D. (1980). Relationship between college teachers' use of humor in the classroom and students' evaluations of their teachers. Journal of Educational Psychology, 72, 511-519. DOI: http://dx.doi. org/10.1037/0022-0663.72.4.511

Chabeli, M. (2008). Humor: A pedagogical tool to promote learning. Curationis, 31(3), 51-59. DOI: http://dx.doi.org/10.4102/curationis.v31i3.1039

Devine, A., Fawcett, K., Szücs, D. i Dowker, A. (2012). Gender differences in mathematics anxiety and the relation to mathematics performance while controlling for test anxiety. Behavioral and Brain Functions, 8(1), 33. DOI: http://dx.doi. org/10.1186/1744-9081-8-33

Evans-Palmer, T. (2009). The relationship between sense of humor and self-efficacy: An exploration of the beliefs of art teachers. San Antonio: University of the Incarnate Word. 
Everson, H. T., Millsap, R. E. i Rodriguez, C. M. (1991). Isolating gender differences in test anxiety: A confirmatory factor analysis of the Test Anxiety Inventory. Educational and Psychological Measurement, 51(1), 243-251.

Frymier, A. B., Wanzer, M. B. i Wojtaszczyk, A. M. (2008). Assessing students' perceptions of inappropriate and appropriate teacher humor. Communication Education, 57(2), 266-288. DOI: http://dx.doi.org/10.1080/03634520701687183

Gorham, J. i Christophel, D. M. (1990). The relationship of teachers' use of humor in the classroom to immediacy and student learning. Communication Education, 39, 46-62. DOI: http://dx.doi.org/10.1080/03634529009378786

Hackathorn, J., Garczynski, A. M., Blankmeyer, K., Tennial, R. D. i Solomon, E. D. (2011). All kidding aside: Humor increases learning at knowledge and comprehension levels. Journal of the Scholarship of Teaching and Learning, 11(4), 116-123.

Harris, J. J. (1989). When jokes are not funny. Social Education, 53, 270.

Howell, D. C. (2002). Statistical Methods For Psychology. Pacific Grove, CA: Duxbury Press.

Laurin-Barantke, L., Hoyer, J., Fehm, L. i Knappe, S. (2016). Oral but not written test anxiety is related to social anxiety. World Journal of Psychiatry, 6(3), 351. DOI: http:// dx.doi.org/10.5498/wjp.v6.i3.351

Ljubotina, D. (2006). Neki metodološki aspekti studentskog vrednovanja nastave. Neobjavljeni rad. Zagreb: Odsjek za psihologiju Filozofskog fakulteta u Zagrebu.

Martin, A. i Marsh, H. (2005). Motivating boys and motivating girls: Does teacher gender really make a difference?. Australian Journal of Education, 49(3), 320-334. DOI: http://dx.doi.org/10.1177/000494410504900308

Martin, R. A. i Ford, T. (2018). The psychology of humor: An integrative approach. Cambridge: Academic Press.

Martin, R. A., Puhlik-Doris, P., Larsen, G., Gray, J. i Weir, K. (2003). Individual differences in uses of humor and their relation to psychological well-being: Development of the Humor Styles Questionnaire. Journal of Research in Personality, 37(1), 48-75. DOI: http://dx.doi.org/10.1016/S0092-6566(02)00534-2

McCabe, C., Sprute, K. i Underdown, K. (2017). Laughter to learning: How humor can build relationships and increase learning in the online classroom. Journal of Instructional Research, 6, 4-7. DOI: http://dx.doi.org/10.9743/JIR.2017.9 
TEA FILEŠ, NINA PAVLIN-BERNARDIĆ: STILOVI HUMORA SVEUČILIŠNIH NASTAVNIKA KAO PREDIKTORI EVALUACIJE NASTAVNIKA I MOTIVACIJSKIH ČIMBENIKA U STUDENATA

Pintrich, P. R. i Schunk, D. H. (2002). Motivation in education: Theory, research, and applications. New Jersey: Prentice Hall.

Pintrich, P. R., Smith, D. A. F., Garcia, T. i McKeachie, W. J. (1991). A manual for the use of the motivated strategies for learning questionnaire (MSLQ). Michigan: National Center for Research to Improve Post secondary Teaching and Learning.

Ryu, E. (2011). Effects of skewness and kurtosis on normal-theory based maximum likelihood test statistic in multilevel structural equation modeling. Behavior Research Methods, 43(4), 1066-1074. DOI: http://dx.doi.org/10.3758/s13428-011-0115-7

Smith, W. G. (2008). Does gender influence online survey participation? A record-linkage analysis of university faculty online survey response behavior. Preuzeto $\mathrm{s}$ https:// files.eric.ed.gov/fulltext/ED501717.pdf (23. siječnja 2021.)

Torok, S. E., McMorris, R. F. i Lin, W. (2004). Is humor an appreciated teaching tool? Perceptions of professors' teaching styles and use of humor. College Teaching, 52, 14-20. DOI: http://dx.doi.org/10.3200/CTCH.52.1.14-20

Tubin, S. (2011). Struktura stilova humora, ličnost i zadovoljstvo životom. Neobjavljeni diplomski rad. Zagreb: Odsjek za psihologiju Filozofskog fakulteta u Zagrebu.

Vernon, P. A., Martin, R. A., Schermer, J. A. i Mackie, A. (2008). A behavioral genetic investigation of humor styles and their correlations with the Big-5 personality dimensions. Personality and Individual Differences, 44(5), 1116-1125. DOI: http://dx.doi. org/10.1016/j.paid.2007.11.003

Veselka, L., Schermer, J. A., Martin, R. A. i Vernon, P. A. (2010). Relations between humor styles and the Dark Triad traits of personality. Personality and Individual Differences, 48(6), 772-774. DOI: http://dx.doi.org/10.1016/j.paid.2010.01.017

Wanzer, M. B. i Frymier, A. B. (1999). The relationship between student perceptions of instructor humor and students' reports of learning. Communication Education, 48, 48-61. DOI: http://dx.doi.org/10.1080/03634529909379152

Wanzer, M.B., Frymier, A.B. i Irwin, J. (2010). An explanation of the relationship between instruction humor and student learning: Instructional humor processing theory. Communication Education, 59, 1-18. DOI:

Wanzer, M. B., Frymier, A., Wojtaszczyk, A. M. i Smith, T. (2006). Appropriate and inappropriate uses of humor by teachers. Communication Education, 55(2), 178-196. 